Egypt. Acad. J. Biolog. Sci., 4(1):1-8 (2012)

Email: egyptianacademic@yahoo.com

Received: 11/2/2012
C. Physiology \& Molecular Biology

ISSN: 2090-0767

www.eajbs.eg.net

\title{
Studies of cytochrome b protein modelling sequence in the Salmo trutta fario and comparing with other salmonids
}

\author{
Abolhasan Rezaei $^{1}$ and Sheyda Akhshabi ${ }^{2}$ \\ 1- Department of Genetics-School of basic science, Islamic Azad University \\ Tonekabon Branch,Iran. \\ 2-Young Researchers Club, Tonekabon Branch, Islamic Azad University, Tonekabon, \\ Iran. \\ Corresponding Author: Abolhasan Rezaei \\ a.rezaei@tonekaboniau.ac.ir \\ Mailing Address: Islamic Azad University Tonekabon Branch-Iran. P.O. Box \\ 4864161187, Tonekabon, Iran
}

\begin{abstract}
The present study represents a preliminary analysis of the cytochrome $b$ protein sequences in the salmo trutta fario, salmo trutta caspius, salmo trutta trutta and salmo salar has been determined. The cytochrome b gene consisting 1141 base pairs that encoding 380 amino acids and has been five origins ORF sites from nucleotides number of 125 to 718 which placed number of $72,40,37,67,32$, respectively from first to end of gene. The amino acids sequences were compared with those of other salmonids such as salmo salar, salmo trutta and salmo trutta caspius, in this regards, the sequences aligned by DNAMAN program computer, results are shown regards salmo salar, salmo trutta trutta has 380 amino acids and same homology almost $99 \%$ but regards salmo truttta caspius, has $78 \%$ homology. There were more variation from 20 first amino acids than other parts of segments, however there is not full length of cytochrome $\mathrm{b}$ gene in samlo trutta caspius. The sequence features of the $3 \mathrm{RD}$ structure protein accessed and compared between species of salmonids, The results are shown there are same homology between structures of protein.
\end{abstract}

Keywords: Salmo trutta fario, sequencing, protein, cytochrome b gene

\section{INTRODUCTION}

The salmonid fishes are one of the best studied native in the world. At present there are major studies on the phylogenetic salmonid population in Norway, Chile, Canada, Scotland (Bernatchez et al., 1992), Iran (Rezaei et al., 2011, a, b,) and elsewhere). In related to, salmonid fishes also are commercially important and the farming of these fish represents a major economics in the world. In Iran Salmo trutta fario and salmo trutta caspius is widely spread in a large number of water streams from the north of Iran, also they are living in South of Caspian Sea that those are endemic in Caspian Sea, these fishes for reproduction migrates to rivers connected to Sea. Vertebrate mtDNA is a circular genome approximately $16 \mathrm{~kb}$ in size in most taxa and contains 37 genes that encode 13 proteins, 22 tRNAs, and 2 rRNAs, compared to other animals and plants, mtDNA among vertebrates is unique in that it lacks introns, consequently genes are tightly packed together(Bernatchez et al., 1992). Recently, have been found the complete sequence of mitochondrial DNA (mtDNA) in human genomic by (Anderson et al., 1981), also, was found the complete sequence in other animals, fungi, plant and other vertebrates and invertebrates (Wolstenholme, 1992). Regards fishes, Wilhelm et al., had reported that 67 sequences deposited in GeneBank, ((NCBI: www.ncbi.nlm.nih.gov/PMGifs/ 
Genomes/ 7898.html). Mitochondrial DNA is great interest parameter for identification, conservation and population genetics studies ((Phillips and Oakley, 1997). To investigate and characterized the genetic differentiation and phylogenetic relationships among between salmonid population at the mtDNA level. However the previously were amplified and has been analyzed for other genetic techniques including, RFLP, and allozymes as well. (Karakousis \& Triantaphyllidis, 1990; Apostolidis et al., 1996; (Avise, 1994; Gyllenstein \& Wilson, 1987; Hynes et al., 1989; Bembo et al., 1994; Hall \& Nawrocki, 1995), but also was followed by the sequence of mtDNA of salmonids, including, cytochrome $\mathrm{c}$ oxidase (three subunits), 16S rRNA, 12S rRNA, ND(six subunits) and cytochrome b. Regards cytochrome $b$ were found sequence of protein in salmo salar,(Hurset et al., 1999, Accession number:U12143) salmo trutta caspius (Jamshidi and Kalbasi, 2009, Accession number: ACN25134), salmo trutta trutta (Duc et al., 2007, Accession number: YP-001568983.1) and salmo trutta fario (Hao et al., 2006, Accession number: ABD52296). Cytochrome b protein in full length has 380 amino acids that including one exon and without intron in full length. Cytochrome $b$ however is important in the respiratory system of cell, has major function belong to marker genetics and studies of population in solmonids (Bernatchez et al., 1992). In this study we examined the codon site of protein coding gene of the cytochrome $b$ to identify what role natural selection may have played in divergence of the cytochrome $\mathrm{b}$ encoded protein among salmonids, what changes, if any, correlate with specific structures within the cytochrome $\mathrm{b}$ protein in other salmonids. In related to was found 380 amino acids from length of cytochrome $b$ in salmo trutta fario, that also same number and has high homology with other salmonids reported in GeneBank system.

\section{MATERIALS AND METHODS} The salmo trutta fario samples:
The samples of Salmo trutta fario has taken on the July 2011 from the Rivers of Tonekabon- Iran, these samples including Bloods and Muscles has taken from three old age females.

\section{Extraction of DNA:}

Genomic DNA was isolated from blood samples following the phenolchloroform extraction method described by Sambrook (1989). Following this method, first, after adding proteinase $\mathrm{k}$ to phenolchloroform reaction, was segregated upper supernatant solution, then added Ethanol $95 \%$ for precipitation of DNA genomic, then, DNA was dissolved in TE buffer and was kept in a water bath at $60^{\circ} \mathrm{C}$ for $2 \mathrm{~h}$ to dissolve pellet properly in buffer. The quality of DNA also was checked through spectrophotometry instrument. DNA samples with O.D. ratio between 1.7 and 1.9 were considered and also the wave length of 260/280 as good and used for further study. The samples also for getting more DNA were re-extracted by the phenol-chloroform extraction method. Then DNA quality was loaded on the gel 1.5 percent agarose for observation quality of band. The DNA samples devoid of smear were used for further study.

\section{The PCR reaction:}

A 1191 bp from cytochrome b gene in the salmo trutta fario by Forward and Reverse primers that were designed by DNAMAN program genetics and blast Network system in NCBI was amplified. These primers including, Forward Primer 5' GAC TTG AAA AAC CAC CGT TG 3'. Reverse Primer 5' CTC CGA TCT CCG GAT TAC AAG AC 3', these primers also were used for sequencing of the cytochrome $\mathrm{b}$ gene. For providing PCR reaction in volume of $5 \mathrm{o} \mu \mathrm{l}$, we used, 100 ng DNA template, $2.5 \mu 1$, 10X sigma PCR buffer, $2.0 \mu \mathrm{l}$ dNTP mix (2.5mM each), 1.0 $\mu 1$ Forward primer $(25 \mathrm{pm} / \mu \mathrm{l}), 1 \mu 1$ Reverse primer $(25 \mathrm{pm} / \mu 1), 0.25 \mu 1$ Sigma Taq DNA polymerase enzyme $(5 \mathrm{U} / \mu \mathrm{l})$. $17.5 \mu$ l. DNA nuclease free water. After that, the PCR-reactions were carried out in a thermocycler in two stages. In the first stage, initial denaturation at $95^{\circ} \mathrm{C}$ for 10 minutes, denaturation at $95^{\circ} \mathrm{C}$ for 1 minute, 
annealing at $55^{\circ} \mathrm{C}$ for 1 minute, extension time at $72^{\circ} \mathrm{C}$ for 1 minute and 10 minute for 35 cycles.

\section{The Sequencing project:}

The PCR products were concentrated to50 $\mathrm{ng} / \mu \mathrm{l}$ by pooling several tubes to precipitate by the isopropanol procedure. In order to obtain clean fragment for sequencing, the PCR products were separated by electrophoresis in a TAE agarose gel containing ethidium bromide using standard protocols (Sambrook et al., 1989). The desired PCR product band was excised using a clean, sterile razor blade or scalpel (band was visualized in a medium or long wavelength (e.g., $\geq 300 \mathrm{~nm}$ ) UV light, and excised quickly to minimize exposure of the DNA to UV light). The minimum agarose slice was transferred to a $1.5 \mathrm{ml}$ micro centrifuge or screw cap tube and then purified by using commercially available gel extraction kits (Qiagen). Quantification was done by loading one $\mu \mathrm{l}$ of eluted sample in 1.5\% agarose gel and comparing with standard molecular marker (Phi X 174 DNA ladder or 500 bp DNA ladder-). Only samples with good concentration $(>50 \mathrm{ng} / \mu \mathrm{l})$ were selected and subjected to sequencing. Regards the sequencing, Products of PCR reaction sequenced directly using either the Thenosequenase sequencing kits (Amersham United States Biochemicals). Sequencing, electrophoresis and autoradiography were performed according to the manufacturer's instructions.

\section{Deposited of DNA sequence in GeneBank:}

The cytochrome $b$ gene was sequenced and deposited in GeneBank by accession number (JN995186.1). The sequence of cytochrome $b$ gene analyzed by DNAMAN program and transferred to Protein structure. The protein structures also analyzed by jigsaw program protein and compared with other structures proteins from other salmonids that reported in GeneBank- NCBI Network system.

\section{RESULTS}

\section{PCR products:}

The PCR product amplified and full length of gene cytochrome b (1191bp.) was runned and put on the 1.5 percent gel electrophoresis. After getting bands, the gel was take photo by Gel DOC instrument. (USA company) and are shown in (Fig.1).

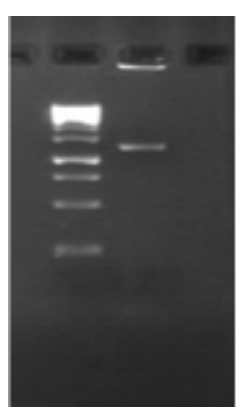

$\mathrm{M} \mathrm{A}$

Fig. 1: PCR amplification of high quality salmo trutta fario using the primers of designed Samples were separated by electrophoresis in $1.5 \%$ gel electrophoresis. A: DNA amplified $1191 \mathrm{bp}$. M. Size marker 1000bp.

Variable of nucleotide and amino acid sequences:

Polymorphism of the genotype of salmo trutta fario cytochrome $\mathrm{b}$ was confirmed by nucleotide sequencing. The nucleotide sequence as well as the derived amino acid sequence of cytochrome $b$ gene of salmo trutta fario by DNAMAN program computer. Nucleotide sequence variations and amino acid variations were observed at the cytochrome $\mathrm{b}$ protein between salmo trutta caspius, salmo salar and salmo trutta trutta reveals almost 98 to $99 \%$ nucleotide identity. (Fig. 2). 

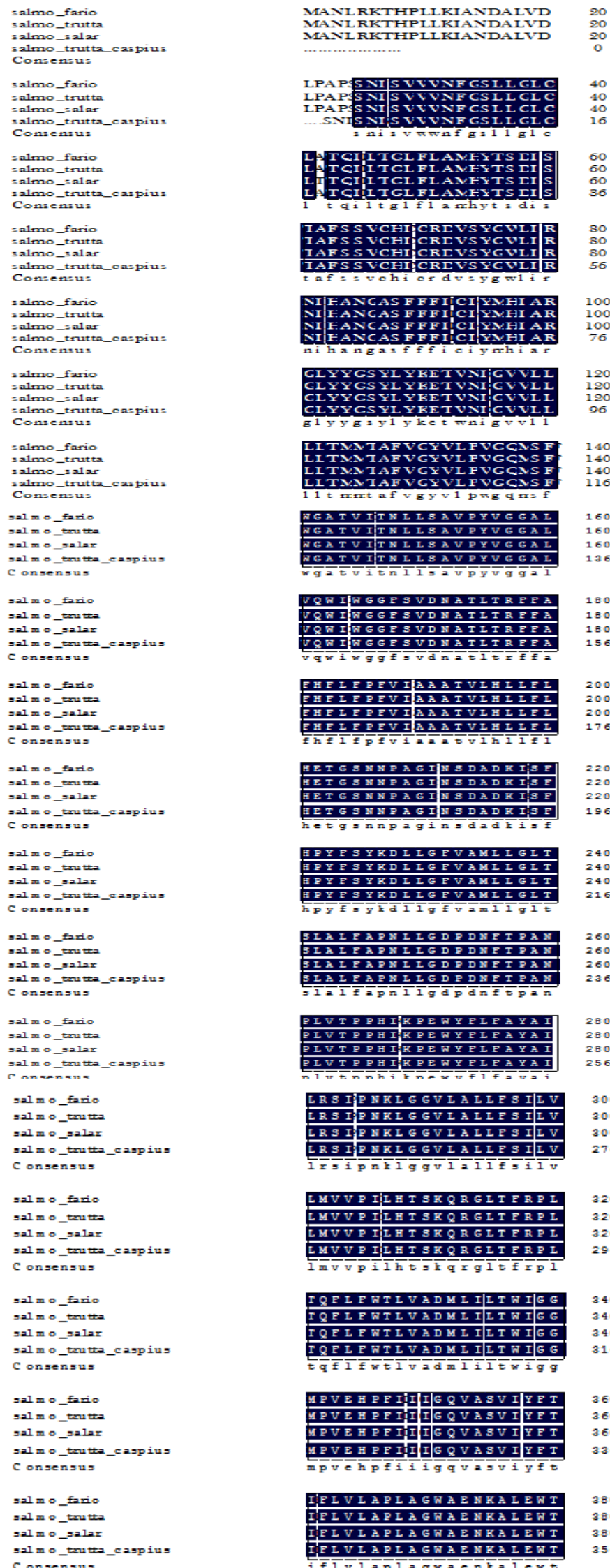

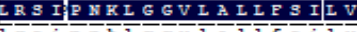
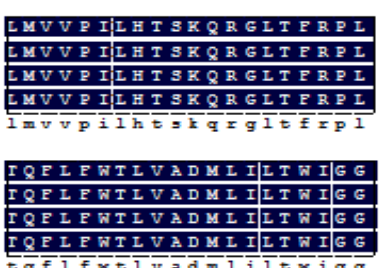

\section{340
340
31}

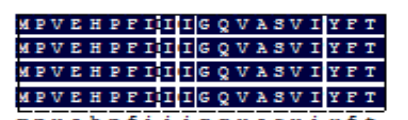

360
360
360
336

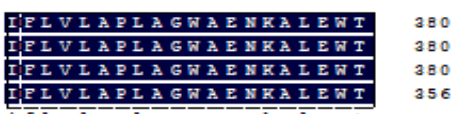

Fig. 2: Sequence alignment of cytochrome $b$ protein for four important species of salmons The amino acids in gray color bold and white bold background The gray background color amino acids were same homology between salmonids, but there were some single nucleotides that different homology. 


\section{Prediction of Three-dimensional protein structure:}

However, the number of ways that a protein can fold appears to be limited, there is considerable optimum that it will be possible to predict the fold of any protein, just given its amino acid sequence, structural alignment studies have revealed on the salmo trutta fario. In threading, the amino acid sequence of a cytochrome $b$ protein is examined for compatibility with the structural of a known protein structure in other salmonids, including, salmo trutta trutta, salmo salar and salmo trutta caspius. In related to we observed from protein core is made up of $\alpha$-helix, $\beta$ strands and other structural elements folded into a protein. In this regards,

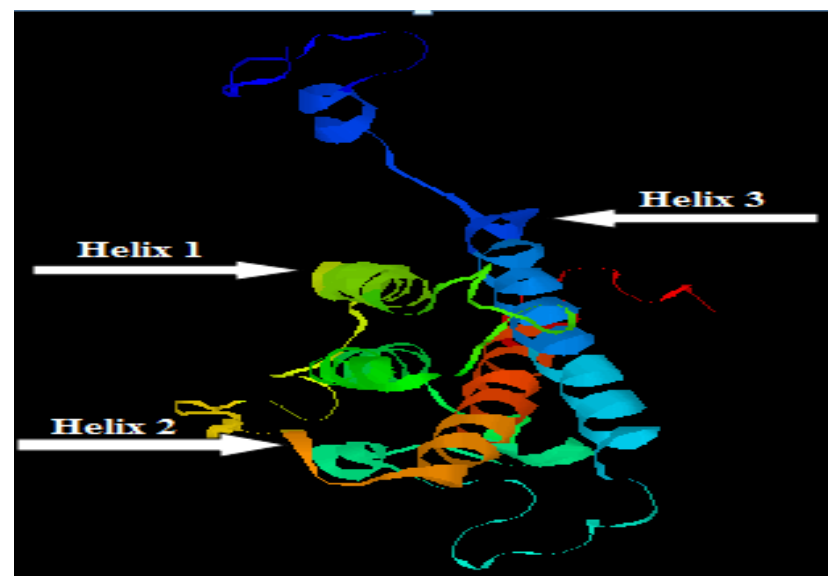

Fig. 3:3-dimensional crystal structure of Complex I from salmo trutta fario. The chains side compared, almost 70 percent from amino acids are involved in $\alpha$-helix formation, which run anti-parallel to each other. These helices attribute to the typical 3- $\alpha$ - helix bundle protein conformation, the characteristic 3-D conformation of cytochrome $b$ protein.
Twenty-four nucleotide sites (from 1 to 26) were variable among the four species examined. (Figs. 3,4,5). Also single mutation including, Threonine (T) and Alanine (A) occurred at nucleotide 42 for salmo trutta trutta, salmo salar and position of 18 in salmo trutta caspius, in fact these mutations are in first part of length. Regards third type of structure that called tertiary protein structure, there is a variety of bonding interactions between the chains that occurred on the amino acids, however these chains may be stronger than hydrogen bonds between side chains. In general, there is a high homology of sequences at the nucleotide and amino acid level when they are compared with other salmonids species.

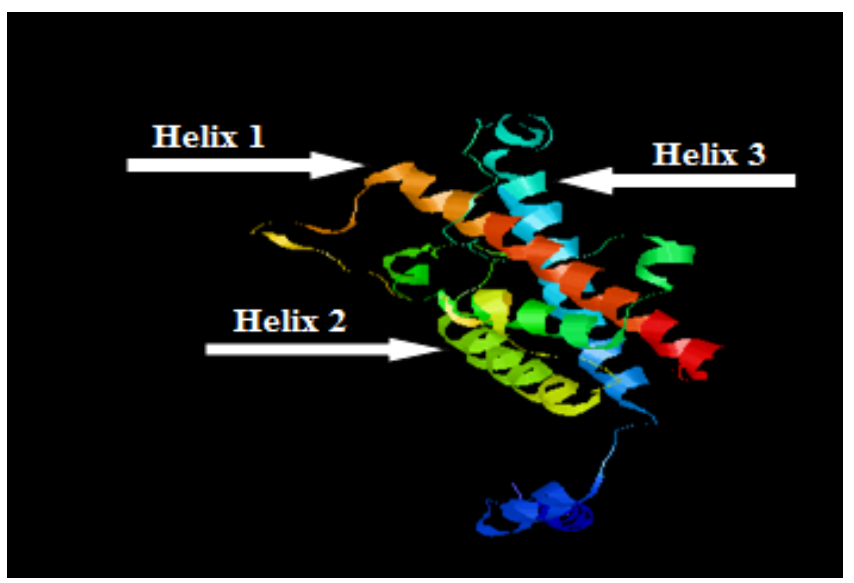

Fig. 4: 3-dimensional crystal structure of Complex I from salmo trutta trutta, The chains side compared, almost 70 percent from amino acids are involved in $\alpha$-helix formation, which run anti-parallel to each other. These helices attribute to the typical $3-\alpha$ - helix bundle protein conformation, the characteristic 3-D conformation of cytochrome $b$ protein

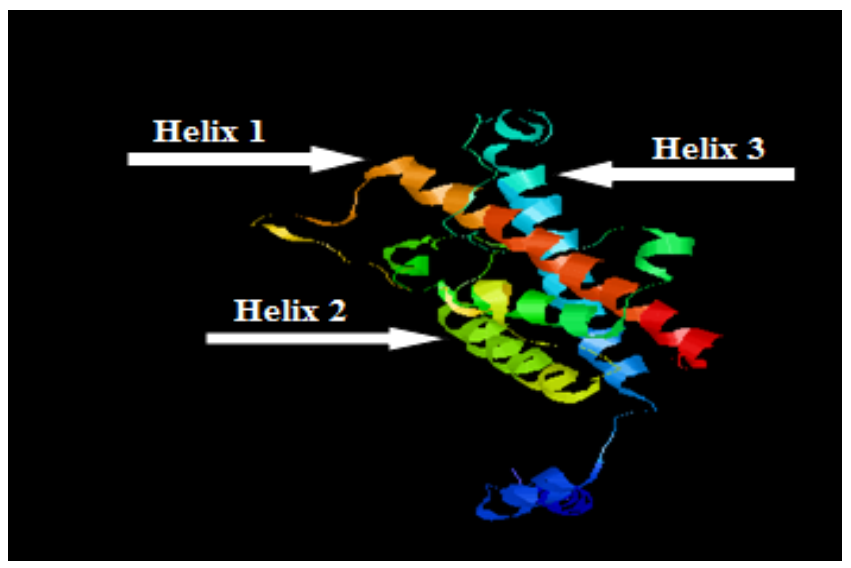

Fig. 5: 3-dimensional crystal structure of Complex I from salmo salar, The chains side compared, almost 70 percent from amino acids are involved in $\alpha$-helix formation. Which run anti-parallel to each other. These helices attribute to the typical 3- $\alpha$ - helix bundle protein conformation, the characteristic 3-D conformation of cytochrome $b$ protein. 


\section{DISCUSSION \\ Cytochrome b gene in Salmons:}

Salmo trutta fario present some interested for biological characteristics for the study of genetic differentiation, they live in the upper part of rivers, and exhibit homing behavior. Therefore the different populations are relatively isolated but can be connected by migration (Aurelle et al., 1998). I the last decade was studied regards genetic variation by allozymes. (Fergusen 1989; Guyomond 1981 and 1989; Hamilton 1989; Pateaux 1995; Garcia-Marin and Pla 1996). Growth hormone gene marker (Rezaei et al., 2011; Gross et al., 1999 and 1995), that determined paternal traits in salmonids, also, mitochondrial genomic (Bernatchez et al., 1992) and microsatellite markers (Aurreli and Berrebi, 1998). All of those markers confirmed the rate of variation in salmonids. Following the discovery of cytochrome $b$ genes in the salmonids (Hurst et al., 1999; Rezaei et al., 2011), the hypothesis of an ancestral mitochondrial genome in bony fishes gained rapid popularity (Bernatchez et al., 1992). This is the first study that analyzed the coding sequences in the cytochrome $\mathrm{b}$ protein, contains $380 \mathrm{bp}$. in the length. In this regards, salmo trutta trutta, salmo salar had been same homology with salmo trutta fario, there is one mutation in amino acid number of 42 between salmo trutta trutta and salmo trutta fario (Alanine) with salmo salar (Threonine). Also there were variation between first 20 amino acids between salmonids and other segment of protein there were not any variation.

The third structure of protein of cytochrome b in Salmo trutta caspius and other Salmons:

In this study were analyzed the protein structures of the cytochrome $b$ gene from Salmo trutta fario with Salmo salar and salmo trutta trutta. Regards salmo trutta caspius there were not complete sequence in GeneBank, so we didn't compare with salmo trutta fario. 3D-structure of the Salmo trutta fario cytochrome $b$ protein is some variation with Salmo salar and salmo trutta trutta. In this regards, in all the known crystallographic and theoretical cytochrome b structures, more than $70 \%$ of the residues are involved in the formation $a$-helix in antiparallel twisted helical bundle. Sequence comparison indicates that the $a$-helical regions are more conserved than other parts of the molecule, suggesting the possibility of similar conformation in all the other proteins of the cytochrome $b$ family. The cytochrome $\mathrm{b}$ in three species, salmo trutta trutta, salmo salar and salmo trutta fario had been three chains helix, but the shape of structure between salmo trutta fario was different with slmo trutta trutta and salmo salar however the results were shown that there were high homology between salmo salar and salmo trutta trutta more than salmo trutta fario. Regards the conformation of Cysteine residues 10 numbers, however the cytochrome had maternal traits, regards paternal traits there were five Cysteine residue in growth hormone protein in the salmo salar (Gross et al., 1995 and Gross et al., 1999), salmo trutta caspius (Rezaei et al., 2011)and salmo trutta trutta (Agelon 1998). Regards Open Reading Frame,(ORF sites)The salmo trutta fario cytochrome b protein contains 5 fragments Open reading frames, that started from nucleotide 125 is methionine and ended to nucleotide of 718 that started codon methionine from position of 135 that was stop codons contains, TAG, TAA, TGA, in the length (Fig. 6).

$\begin{array}{cllc}\text { Strand } & \text { RF } & \text { AA } & \text { Num } \\ \text { Plus } & 2 & 72 & 125-343 \\ \text { Plus } & 3 & 40 & 615-737 \\ \text { Plus } & 1 & 37 & 883-996 \\ \text { Minus } & 3 & 67 & 420-623 \\ \text { Minus } & 2 & 32 & 620-718\end{array}$

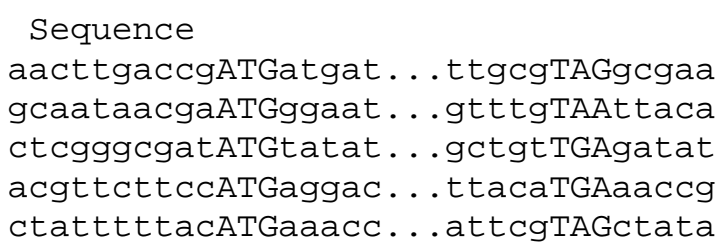

Sequence aacttgaccgATGatgat . . . ttgcgTAGgcgaa gcaataacgaATGggaat. . .gtttgTAAttaca ctcgggcgatATGtatat . . .gctgtTGAgatat acgttcttccATGaggac....ttacaTGAaaccg ctatttttacATGaaacc . . . attcgTAGctata

Fig. 6: Open Reading Frame (ORF) nucleotides in the cytochrome b gene in salmo trutta fario. There are five segments ORF. Was started from nucleotide of 125. 


\section{ACKNOWLEDGMENTS}

This work had financially supported by the research council of Islamic Azad University Tonekabon branch.

\section{REFERENCES}

Agelon L. B. (1998): Promotion of rapid growth of rainbow trout (Salmo gairdneri) by a recombinant fish growth hormone. Can. J. Fish. Aquat. Sci., 45: 146-151.

Apotolidis A. P.; Karakousis Y.; Triantaphyllidis. (1996). Genetic divergence and phylogenetic relationships among brown trout (Salmo trutta L.) populations from Greece and other European countries. Heredity., 76: 551-560.

Anderson S, Bankier., A.T., Barrell., B.G., D.E., Bruijn M.H., Coulson AR, Drouin J., Epero I.C., Nierlich D.P., Roe B.A., Sanger A. F., Schreier P.H., Smith A.J., Staden R., Young I.G. (1981). Sequence and organization of the human mitochondrial genome. Nature., 290: 457-465.

Aurelle D., and Berrebi p. (1998). Microsatellite markers and management of brown trout (salmo trutta fario) populations in southwestern France. Genetic selection evolution., 30: 575-590.

Avise J.C., Arnold J., Ball R.M., (1987). Intraspecific phylogeography: the mitochondria1 DNA bridge between population genetics and systematics. Annual Reviaus of Ecology and

Systematics., 18: 489-522.

Bernatchez, L., Guyomard, R. and Bonhomme, F. (1992). DNA sequence variation of the mitochondrial control region among geographically and morphologically., remote European brown trout Salmo trutta populations. Molecular Ecology., 1:161-1 73.

Bembo D. O., Weightman, A. J., Beverton, R. J. Cresswell R. C. (1994)., Mitochondrial DNA variation in River Usk brown trout, Salmo trutta. .L. Fish Biol., 44: 717-723.
Duc,M., Karlsen,B.O. and Moum,T.(2007). The mitochondrial genome of Salmo trutta, intraspecific variation and comparison to other salmonid mitochondrial genomes Unpublished.

Ferguson A. (1989). Genetic differences among brown trout, salmo trutta stocks an importance for the conservation and management of the species Freshwater Biology., 21: 35-46.

Hall, H.J. and Nawrocki, L.W. (1995). A rapid method for detecting mitochondrial DNA variation in the brown trout, Salmo trutta. Journal of Fish Biology., 46: 360-364.

Hao F. and Chen,Y., (2006). Mitochondrial DNA and microsatellite markers reveal the genetic structure of Salmo trutta fario $L$. from Yadong River, Tibetan Plateau. Unpublished.

Hurst,C.D., Bartlett,S.E., Davidson,W.S. and Bruce,I.J. (1999). The complete mitochondrial DNA sequence of the Atlantic salmon, Salmo salar. Gene., 239 (2): 237-242.

Hamilton K.E., Ferguson A., Taggart J.B., Tomasson T., Walker A., Fohy E., (1989). Post-glacial colonization of Brown trout, salmo trutta $L$. :Ldh-5 as a phylogeographic marker locus, J. Fish Biology., 35: 651-664.

Hynes, R. A., Duke, E. J., Jouce P.,(1989). Mitochondrial DNA as a genetic marker for brown trout, Salmo trutta L., populations. J. Fish Biol., (35), 687-701.

Garcia-Marin J.L., Pla C., (1996). Origins and relationships of native populations of Salmo troutta(Brown trout) in Spain,. Heredity., 77: 313-323

Gross R.\& Nilsson J. (1995). Application of heteroduplex analysis for detecting variation within the growth hormone 2 gene in (Salmo trutta L.) brown trout. Heredity., 74: 286-295.

Gross R. \& Nilsson J. (1999). Restriction fragment length polymorphism at the growth hormone 1 gene in Atlantic salmon (Salmo salar L.) and its association with weight among the offspring of a hatchery stock. Aquaculture., 17 (3): 73-80.

Guyomard R., Krieg F. (1986). Mise en evidence d'un flux genetique entre 
populations naturelles de truite fario et souche de repeuplement dans deux rivieres de Corse, Bull.Fr. Peche Piscic., 303: $134-140$

Guyomard R., Diversite genetique de la truite commune., (1989). Bull. Fr. Peche Piscic., 314: 118-135.

Gyllensten, U. and Wilson A. C. (1987). Mitochondrial DNA of salmonids: Inter and intraspecific variability detected with restriction enzymes. In: Ryman, $\mathrm{N}$. and Utter, F., (eds) Population Genetics and Fishery Management. 301-317. University of Washington Press,

Jamshidi S. and Kalbassi M.R. Direct Submission Submitted. (2009). Marine Science and Fisheries, Unpublished.

Karakousis Y. and Trjantaphyllidis C., (1990). Genetic structure and differentiation among Greek brown trout (Salmo trutta L.) populations. Heredity., 64: 297-304.

Pateaux C., Interactions genetiques entre formes sauvages et formes domestiques chez la truite commune (Salmo trutta fario L.), (1995). these, university Montpellier II, France.
Phillips R.B., Oakley T.H. (1997). Phylogenetic relationships among the Salmonidae based on nuclear DNA and mitochondrial DNA sequences. In: Kocher T., Stepien C (eds) Molecular Systematic of Fishes. San Diego: Academic Press. 145-162.

Rezaei A., Akhshabi S.H., Jamalzadeh H.R., (2011). Investigation and Identification salmo trutta caspius by the Growth Hormone type 1 (GH1) gene analogue. B.J.Biotech., 3: 76-82.

Rezaei A., Akhshabi S.H., Jamalzadeh H.R., (2011)., Sequencing and sequence analysis of Growth Hormone type 1 (GH1) gene homologue in the salmo trutta caspius. Adv. S. Biol., 3:111-122.

Sambrook J., Fritsch E. F., Maniatis T., (1989). Molecular Cloning: A Laboratory Manual. 2 ${ }^{\text {nd }}$. Cold Spring Harbor Laboratory Press, Cold Spring Harbor, N.Y.

Wolstenholme D.R., (1992) Animal mitochondrial DNA structure and evolution. Int. Rev. Cytol., 141:173-216 